\title{
DATA,KRITERIA,PEMBINAAN DAN PENGEMBANGAN PONDOK PESANTREN SEKOTA PALANGKA RAYA
}

\author{
'Rip'ah \\ 'Pasca Sarjana IAIN Palangka Raya
}

\begin{abstract}
Abstrak
Metode yang digunakan dalam Penelitian ini menggunakan metode penelitian deskriptif, yaitu suatu metode yang meneliti suatu objek, sekelompok manusia, suatu kondisi, atau sistem pemikiran atau pun suatu kilas peristiwa sekarang, yakni masalah-masalah yang sedang aktual. Sedangkan sumbernya diambil dari sumber primer yaitu Pondok Pesantren di Kota palangka Raya dan Sumber sekunder yang di ambil dari beberapa buku-buku ilmiah yang diterbitkan dengan maksud dijadikan sumber referensi.Tujuan penelitian ini untuk mendeskripsikan data, kriteria, pembinaan dan pengembangan Pondok Pesantren se Kota Palangka Raya. Penelitian ini menunjukan bahwa, Data, Kriteria, Pembinaan dan Pengembangan pada Pondok Pesantren yang dilakukan oleh Kementerian Agama Kota Palangka Raya melalui wawancara dengan Kasi Pendidikan Diniyah dan Pondok Pesantren dapat meningkatkan Pondok Pesantren dari yang sifatnya tradisional ke arah mandiri dan berdaya saing dalam menciptakan efektifitas karya tidak hanya menonjol dari skill pengetahuan tentang keagamaan saja, namun juga memberikan life skill kepada santri . Kata Kunci : Data,Kriteria, Pembinaan, Pengembangan, Pondok Pesantren.
\end{abstract}

\begin{abstract}
The method used in this research is descriptive research method, which is a method that examines an object, a group of people, a condition, or a system of thought or a flash of current events, namely the actual problems. While the sources are taken from primary sources, namely Islamic Boarding Schools in Palangka Raya City and secondary sources are taken from several scientific books published with the intention of being used as reference sources. Raya. This study shows that, Data, Criteria, Guidance and Development of Islamic Boarding Schools carried out by the Ministry of Religion of the City of Palangka Raya through interviews with the Head of Early Education and Islamic Boarding Schools can improve Islamic Boarding Schools from being traditional to independent and competitive in creating work effectiveness. not only stands out from the knowledge skills about religion, but also provides life skills to students.
\end{abstract}

Keywords: Data, Criteria, Coaching, Development, Islamic Boarding School. 
Rip'ah, 2021,Data,Kriteria,Pembinaan Dan Pengembangan Pondok Pesantren Sekota Palangka Raya

\section{A. PENDAHULUAN}

Pondok pesantren atau sering juga disebut pesantren diakui sebagai model lembaga pendidikan Islam di Indonesia. Sejak zaman para pendakwah di tanah Jawa, Walisongo, sekitar abad 15, lembaga ini mulai berkembang. Pesantren juga berkembang menjadi lembaga sosial kemasyarakatan melalui inovasi-inovasi yang dilakukannya, seperti sebagai lembaga keagamaan dan lembaga pendidikan. Pesantren yang berkembang melalui inovasi yang di lakukannya dari lembaga pendidikan menjadi lembaga pemberdayaan masyarakat mempunyai pengaruh yang kuat di masyarakat dan terbukti telah memberikan banyak sumbangsih dalam peningkatan kesejahteraan masyarakat.

Dalam hal ini, penting bagi setiap pemangku kepentingan untuk memahami bahwa kedudukan pesantren memiliki aplikasi tidak hanya dalam bidang pendidikan, tetapi juga dalam bidang dakwah dan pemberdayaan masyarakat. Ini adalah faktor penentu di mana, terlepas dari kenyataan bahwa pesantren sudah lama keberadannya, pesantren tetap eksis menjadi bagian integral kekuatan bangsa.Atas inisiasi dan peran masyarakat, pesantren lahir dan berkembang dan sudah menjangkau masyarakat luas. Memisahkan pesantren dengan masyarakat dapat menyebabkan melemahnya eksistensi pesantren, yang selama ini menjadi kekuatan strategi dalam masyarakat. Pesantren dan masyarakat menjalin hubungan mutualisme, saling membutuhkan dan interdependent (saling bergantung satu sama lain).
Menurut Nurcholish Madjid, pesantren telah ada di Indonesia sejak zaman kekuasaan Hindu-Buddha, dan Islam tinggal bersama untuk mengislamkan lembaga yang sudah ada. Pesantren telah melekat dengan makna keislaman, dan juga mengandung kemurnian budaya indonesia, karena itu (indigenous).

Untuk menegakkan kembali sistem tata nilai yang ada dalam lembaga pendidikan klasik, perlu memperhatikan hal-hal berikut: I.Pesantren adalah produk budaya indonesia yang harus dijaga dan dipelihara untuk kekayaan budaya. 2. Pesantren memiliki pendidikan yang kaya dengan nilai-nilai ketaatan kepada TuhanNya dan bersifat kerohanian dinilai sangat efektif dalam menjaga moralitas bangsa di tengah arus dekadensi moral generasi muda. 3.Pesantren sebagai lembaga pendidikan yang dinilai lebih dekat dan mengetahui seluk beluk masyarakat yang oleh David C Korten dapat dipandang sebagai wadah yang paling tepat dalam melakukan perubahan nilai budaya bangsa yang kini mulai di lupakan. Mempertimbangkan ketiga hal tersebut Sutomo, seorang cendekiawan berusia 30 tahun, pernah memikirkan agar sistem pendidikan pesantren dijadikan sebagai dasar pembangunan pendidikan nasional Indonesia.

Terlepas dari kenyataan pandangan tersebut kurang mendapat perhatian, memperhatikan kenyataan pendidikan umum saat ini yang gagal dalam menanamkan nilai-nilai moral pada peserta didik, gagasan Sutomo tersebut kiranya patut direnungkan kembali. Maksud tersebut harus dipahami dalam konteks mendialogkan kekayaan 
budaya asli Indonesia di tengah perkembangan dunia yang kian bersaing saat ini, gagasan ini harus diketahui dalam usaha mendialogkan kekayaan budaya pendidikan pesantren dengan contoh pesaingan pendidikan modern dalam bingkai mempertahankan budaya asli ( cultural resistance ) Adagium “ Al-muhafazatun alal qadiis sholeh wal-akhadzu alal jadiid al-alah," ( melestarikan tradisi yang baik dan mengambil sesuatu yang baru yang lebih baik ) di harapkan dapat menjadi platform normatif dalam menata dialektika pesantren dengan dinamika sosial kehidupan modern. Berdasarkan uraian diatas, maka kami hadirkan tulisan ini sebagai bagian dari upaya memelihara nilai-nilai tradisi pendidikan yang ada di pesantren untuk kemudian dapat disharing dengan nilai-nilai baru yang sesuai dengan konteks.Adapun tulisan ini menyajikan tentang Data,Kreteria,dan Pembinaan serta Pengembangan pada Pondok Pesantren di Kota Palangka Raya.

\section{B. PEMBAHASAN}

\section{DATA PONDOK PESANTREN}

Pada dasarnya data merupakan sekumpulan informasi atau juga keterangan - keterangan dari suatu hal yang diperoleh dengan melalui pengamatan atau juga pencarian ke sumber sumber tertentu. Data yang diperoleh ini dapat menjadi satu anggapan atau fakta, karena memang belum diolah dengan lebih baik. Setelah diolah melalui penelitian atau percobaan maka data tersebut dapat di ubah menjadi bentuk yang lebih kompleks seperti database, informasi, atau bahkan menjadi solusi dari masalah yang di hadapi. Dari segi Bahasa kata "data” ini diambil dari kata "datum” yang dalam Bahasa Romawi memiliki arti memberi. Oleh sebab itu itu definisi sesungguhnya dari data ini adalah diberikan bukan memberikan, sebab apabila memberikan maka data itu sudah menjadi informasi yang baku serta juga diakui kebenarannya. Istilah data biasanya lebih banyak ditemui pada bidang komputer atau juga dalam konteks sebuah penelitian.

Dalam bidang komputer sendiri anda pasti tidak asing dengan yang namanya database maupun juga software pengolah data. Sebaliknya, jika dalam konteks penelitian, sudah menjadi suatu keharusan bahwa setiap peneliti terlebih dahulu harus mencari data dengan melakukan observasi sebelum menyampaikan lebih rinci. dan akhirnya akan diperoleh hasil penelitian. Hal tersebut juga sering dijumpai dalam bidang pendidikan seperti pembuatan jurnal ataupun skripsi.

Begitu juga pada penyelenggaraan Pondok Pesantren tentunya juga memerlukan Data untuk kelengkapan administrasi. Data dan informasi terkait izin operasional pondok pesantren merupakan satu kesatuan data dan informasi pada Kementerian Agama, dengan pengelolaan sebagaimana ketentuan yang diatur melalui Keputusan Menteri Agama Nomor 440 Tahun 2018 tentang Pengelolaan Data dan Informasi Pada Kementerian Agama. Data di maksud adalah Data Emis (Education Management Information System),yang merupakan sistem informasi yang dikembangkan oleh Kementerian 
Rip'ah, 202I,Data,Kriteria,Pembinaan Dan Pengembangan Pondok Pesantren Sekota Palangka Raya

Agama untuk memudahkan input data sekolah,

pondok pesantren dan pendidikan tinggi Islam. untuk semua kelengkapan administrasi pada pondok pesantren.Data Emis juga di gunakan sebagai sumber untuk pengambilan kebijakan (Operator Emis : 2021)

Adapun fungsi dari Data secara umum adalah sebagai berikut :

I. untuk membuat keputusan terbaik didalam memecahkan sebuah masalah,

2. dapat dijadikan juga sebagai dasar suatu perencanaan atau juga penelitian,

3. dijadikan sebagai acuan dalam tiap-tiap implementasi suatu kegiatan atau aktivitas .

4. data ini juga dapat dijadikan sebagai bahan evaluasi.

Data Pondok Pesantren seKota Palangka Raya yang terdaftar pada Kementerian Agama sebagai berikut :

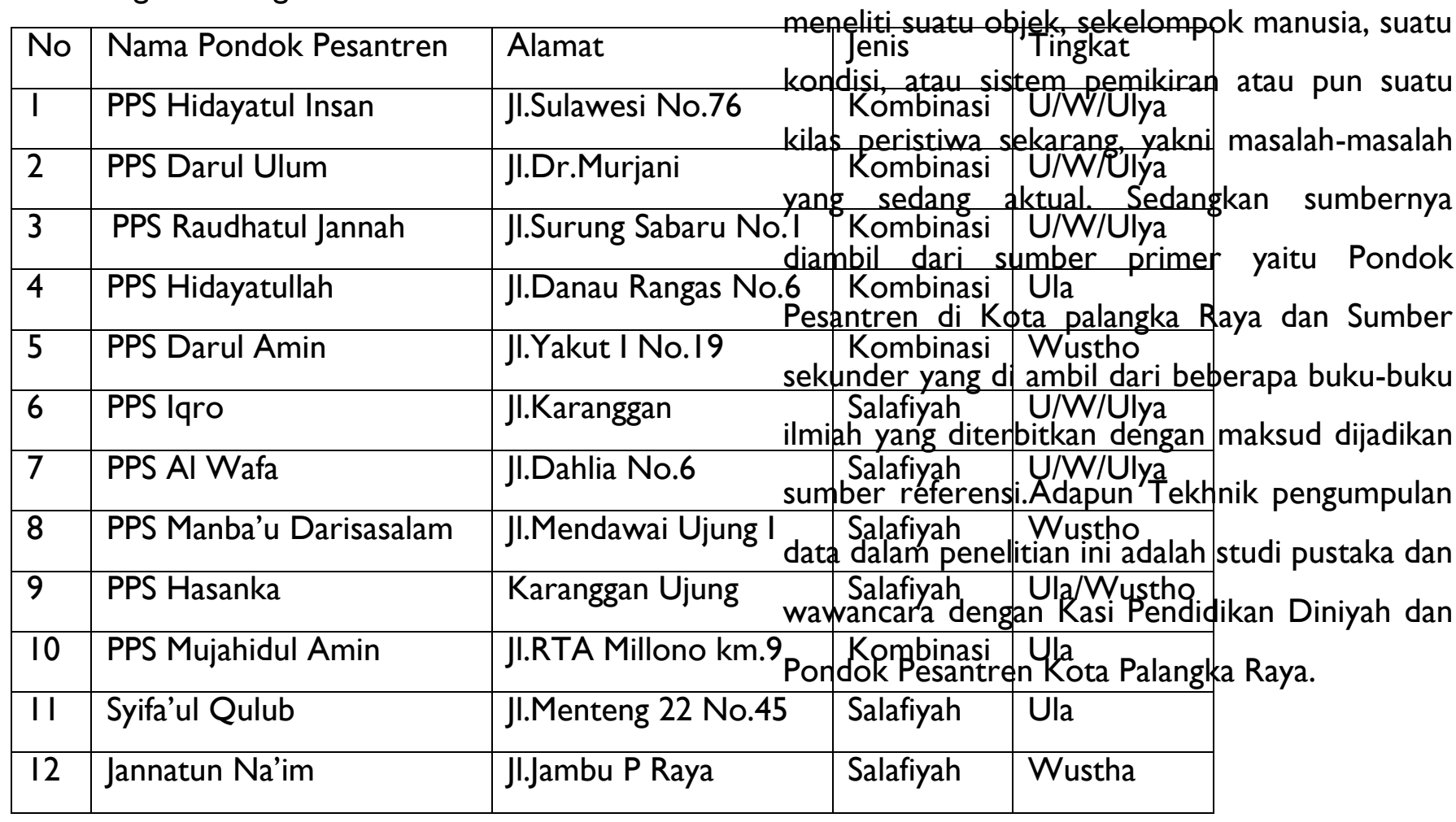

fungsi dakwah, dan fungsi pemberdayaan masyarakat, tujuan pesantren, serta acuan umum mengenai unsur-unsur pesantren, ketentuan mengenai pendaftaran pesantren, ketentuan mengenai penyelenggaraan pesantren, dan ketentuan mengenai pengelolaan data dan informasi pada Kementerian Agama, menjadi dasar dalam menetapkan ketentuan lebih lanjut mengenai pendaftaran pesantren dalam bentuk izin operasional pondok pesantren. Ketentuan lebih lanjut tersebut, diperlukan dengan tujuan untuk menjamin efektivitas, efisiensi, transparansi, dan akuntabilitas proses yang terkait dengan izin operasional pondok pesantren.

\section{METODE PENELITIAN}

Penelitian ini menggunakan metode penelitian deskriptif, yaitu suatu metode yang meneliti suatu objek, sekelompok manusia, suatu kondisi, atau sistem pemikiran atau pun suatu ilas peristiwa sekarang yakni masalah-masalah ano sedang aktual Sedangkan sumbernya liambil dari sumber primer yaitu Pondok 6 Kombinasi Ula 


\section{KRITERIA PONDOK PESANTREN}

Pesantren adalah lembaga yang berbasis keagmaan dan didirikan oleh masyarakat dengan menanamkan keimanan dan ketakwaan kepada Allah SWT, menyemaikan akhlaqul karimah, serta memegang teguh ajaran Islam yang rendah hati (tawadhu), toleran (tasamuh), keseimbangan (tawazun), moderat (tawasuth), dan menanamkan nilai-nilai luhur bangsa Indonesia lainnya melalui pendidikan, dakwah Islam rahmatan lil'alamin, keteladanan (uswah), dan khidmah.

Lembaga pondok pesantren harus memenuhi 5 (lima) unsur yang harus terpenuhi secara integral oleh institusi pesantren (Arkanul Ma'had), yaitu:

I. Kyai / Ustadz atau Sebutan lain sejenis.

Kyai, Tuan Guru, Syekh, Ajengan, Ustadz,Ustadzah, atau sebutan lain sesuai dengan sebutan khas wilayah masing-masing yang menunjukkan kompetensi keagamaan dan kemampuan sosial yang sangat baik. Hadirnya pada pondok pesantren sebagai seorang pendidik atau ulama yang memiliki kompetensi ilmu agama agama yang mumpuni dan berperan sebagai figur, teladan, dan/atau pengasuh pada Pondok Pesantren .

Kyai/Ustadz atau sebutan lain wajib berpendidikan pesantren dan/atau pendidikan tinggi keagamaan Islam yang memiliki kompetensi ilmu agama dan keaagamaan Islam. Selain Kyai/Ustadz, Pesantren dapat memiliki tenaga pendidik dan tenaga kependidikan yang diperlukan dengan kompetensi sesuai kebutuhan Pesantren.

2. Santri Mukim
Santri yang mukim di Pesantren menetap di dalam pondok atau asrama pesantren minimal I5 orang santri dalam satu ruang kelas dan umumnya berdomisili jauh dari pondok, selama 24 (dua puluh empat) jam dalam sehari para Santri diarahkan dalam pembentukan perilaku akhlakul karimah, peningkatan penguasaan Bahasa dan pendalaman kajian kitab kuning atau dirasah islamiyah dengan pola pendidikan mu'allimin, serta perbaikan dan peningkatan pengamalan ibadah.

Selain Santri yang mukim pesantren dapat memiliki santri lain yang hanya ingin belajar pada waktu tertentu, seperti hanya mengaji saja, santri tidak mukim ini biasanya dikenal dengan sebutan santri kalong. Namun, keberadaan santri kalong ini tidak menjadi bagian dari unsur pesantren.

\section{Pondok atau Asrama Pesantren}

Pondok atau asrama sebagai tempat tinggal santri yang mukim selama masa proses pendidikan di Pesantren. Pondok atau asrama bagi santri merupakan ciri khas tradisi pesantren yang membedakannya dengan sistem pendidikan tradisional di masjid-masjid yang berkembang di kebanyakan wilayah Islam di Negara-negara lain. Sistem pendidikan surau di daerah Minangkabau atau Dayah di Aceh pada dasarnya sama dengan sistem pondok, hanya namanya saja yang berbeda. Pondok atau asrama ini tidak harus berupa gedung atau bangunan khusus, tetapi dapat juga berupa ruang yang ada di lingkungan pesantren sebagai tempat tinggal santri sebagaimana tradisi dan kondisi pesantren tersebut. 
Rip'ah, 2021,Data,Kriteria,Pembinaan Dan Pengembangan Pondok Pesantren Sekota Palangka Raya

Agar Pesntren dapat berfungsi dengan baik, pondok atau asrama pesantren tersebut tentunya wajib memenuhi aspek daya tampung, kenyamanan, kebersihan, kesehatan, dan keamanan.

4. Masjid atau Mushalla

Masjid atau mushalla digunakan untuk melaksankan ibadah dan pelaksanaan proses belajar-mengajar santri, serta dapat juga digunakan untuk kegiatan masyarakat di sekitar pesantren untuk memperingati hari-hari besar Islam. Hal ini dimaksudkan agar terjadi interaksi antara pesantren dengan masyarakat dan menghindari eksklusivisme pesantren.

Masjid atau mushalla tidak harus berupa gedung atau bangunan khusus, tetapi bisa juga berupa ruang khusus yang ada di lingkungan pesantren yang dapat di gunakan sebagai tempat pelaksanaan ibadah dan pelaksanaan proses belajar-mengajar santri sebagaimana tradisi dan kondisi pesantren tersebut.

Agar dapat menjalankan fungsinya, masjid atau musholla pesantren tersebut tentunya wajib memenuhi aspek daya tampung, kenyamanan, kebersihan, kesehatan, dan keamanan.

5. Kajian kitab kuning atau dirasah islamiyah dengan pola pendidikan mu'allimin

Kajian kitab kuning atau dirasah islamiyah dengan pola pendidikan mu'allimin adalah unsur wajib dalam penyelenggaraan pesantren yang menjadi dasar untuk menjelaskan varian pesantren.

Kajian kitab kuning atau dirasah islamiyah dengan pola pendidikan mu'allimin dilaksanakan secara sistematis, terintegrasi, dan komprehensif. Yang dimaksud dengan "sistematis" adalah kajian kitab kuning atau dirasah islamiyah dengan pola pendidikan mu'allimin disusun dalam bentuk bahan kajian terstruktur untuk mencapai kompetensi tertentu. Maksud dari "terintegrasi" adalah kajian kitab kuning atau dirasah islamiyah dengan pola pendidikan mu'allimin yang dilaksanakan secara terintegrasi dengan pola pengasuhan di Pesantren. Adapun yang dimaksud dengan “komprehensif' adalah kajian kitab kuning atau dirasah islamiyah dengan pola pendidikan mu'allimin mencakup keseluruhan aspek pengetahuan, wawasan, dan sikap.

Kajian kitab kuning merupakan kajian berbagai literatur yang biasanya dikaji dari awal hingga akhir dalam bentuk kajian khas pesantren seperti Al-Quran, Tafsir, Ilmu Tafsir, Hadits, Ulum Al-Hadits, Tauhid, Fiqh, Ushul Fiqh, Akhlak, Tasawuf, Tarikh, Bahasa Arab, NahwuSharf, Balaghah, IImu Kalam, IImu 'Arudl, IImu Manthiq, Ilmu Falaq, dan disiplin ilmu lainnya, dan/atau dalam bentuk program takhasus yang meliputi tahfizh al-Qur'an, ilmu falaq, faraid, dan cabang dari ilmu keislaman lainnya. Dirasah islamiyah dengan pola pendidikan mu'allimin merupakan kumpulan kajian tentang ilmu agama Islam yang tersusun secara terstruktur, sistematik dan terorganisasi yang bersifat integratif menggabungkan ilmu agama dengan ilmu umum yang bersifat komprehensif dengan memadukan intra, ekstra dan kokurikuler, yang oleh sebagian pesantren dikenal dengan sebutan sistem madrasy.

Akan tetapi, baik kajian kitab kuning maupun dirasah islamiyah dengan pola pendidikan 
mu'allimin, keduanya memiliki 3 (tiga) kriteria dasar, yaitu: (I) menggunakan literatur yang memiliki akar historis-akademis dengan pesantren; (2) kandungannya sesuai nilai-nilai Islam-keindonesiaan, yakni menjunjung tinggi nilai-nilai Pancasila, Undang-Undang Dasar 1945, Negara Kesatuan Republik Indonesia, Bhineka Tunggal Ika, keadilan, toleransi, kemanusiaan, keikhlasan, kebersamaan, dan nilai-nilai luhur lainnya; dan (3) mengembangkan pemikiran yang tawasuth, tawazun, moderat, inklusif, santun, dan menghargai perbedaan budaya lokal.

\section{PEMBINAAN PADA PONDOK PESANTREN}

Pembinaan bagian dari upaya memelihara, menumbuhkan, mengembangkan, menyempurnakan dengan kata lain membawa pada keadaan yang lebih baik. Tim Penyusun Kamus Pusat Pembinaan dan Pengembangan Bahasa merumuskan definisi pembinaan merupakan suatu usaha atau tindakan dan kegiatan yang dilakukan secara berdaya guna untuk memperoleh hasil yang lebih baik. Menurut Wagnel dan Funk dalam Sunarti bahwa pembinaan itu meliputi menjaga serta memberi bimbingan menuju pertumbuhan kearah kedewasaan dengan memberikan pendidikan, tuntunan dan sebagainya terhadap mereka yang dibina.

Dengan pengertian tersebut, pembinaan di pondok dapat dimaknai sebagai upaya untuk menumbuh kembangkan potensi yang di miliki para santri untuk berkembang secara menyeluruh. Pembinaan dimaksudkan secara substransial sebagai upaya pembentukan pribadi santri agar menjadi lebih baik. Pembentukan keperibadian ini dilakukan untuk menggali potensi ketika terjun kemasyarakat nantinya guna dapat bersaing dan di kembangkan serta berdaya guna dan dapat diaplikasikan dalam kehidupannya.

Sistem pembinaan pada pesantren hampir sama dengan konsep pola pengasuhan karena dalam dunia pesantren, para santri lebih condong pada proses pengasuhan dan bimbingan. Hal ini disebabkan karena pengasuhan lebih mendalam dan informal sifatnya dari pada pembinaan yang cenderung sistematis dan formal.Sistem pembinaan adalah bentuk perlakuan atau tindakan pengasuh untuk memelihara,melindungi, mendampingi, mengajar dan membimbing anak selama masa perkembangan. Pengasuhan berasal dari kata asuh yang mempunyai makna menjaga, merawat dan mendidik anak yang masih kecil. sistem pembinaan di pesantren hakikatnya adalah totalitas dari seluruh rangkaian kegiatan pembinaan di pondok dengan komponenkomponennya yang saling mempengaruhi dan terpadu dalam suatu sistem yang diarahkan pada pencapaian tujuan pendidikan yaitu membentuk kepribadian santri yang islami.

Berbicara tentang sistem pembinaan di pondok pesantren, tidak terlepas dari tujuan utama lembaga tersebut, yakni mengajarkan dan mengembangkan ilmu keislaman dengan misi yang telah di tetapkan yaitu tafaqqahu fiddin. Selanjutnya, Muhammad Idris Jauhari membagi 
Rip'ah, 202I,Data,Kriteria,Pembinaan Dan Pengembangan Pondok Pesantren Sekota Palangka Raya misi pesantren dalam dua jenis, yaitu: misi umum pemahaman bahwa sistem pembinaan di dan misi khusus. Misi umum untuk mempersiapkan sumber daya manusia (SDM) yang berkualitas imaniah, ilmiah dan amaliah. Sedangkan, misi khusus untuk mempersiapkan kader-kader pemimpin umat (Munzirul Qaum) yang benar-benar memahami agamanya.

Dalam usaha merealisasikan misinya yang transendental tersebut, pesantren memulai kiprahnya di masyarakat dalam dualisme peran yang diembannya sekaligus sebagai lembaga pendidikan dan sebagai lembaga penyiaran agama islam. Hal ini sejalan dengan penegasan dari Manfred Ziemik yang menyatakan bahwa: sejak tahun 1970-an telah muncul pendapat atau pengalaman baru, bahwa pensatren bukan hanya lembaga pendidikan islam tetapi sekaligus sebagai lembaga sosial. Oleh karena itu, lanjut Ziemik perlu dilakukan kajian secara terpisah antara fungsi pendidikan keagamaan pesantren dan fungsi pembangunan lingkungan.

Pesantren sebagai lembaga pendidikan berdasarkan pada peran dan fungsinya dalam menyelenggarakan pendidikan formal (madrasah, sekolah umum, bahkan perguruan tinggi) dan pada pendidikan non formal yang secara khusus mengajarkan agama khususnya dalam bidang fiqh, hadits, tauhid, tafsir dan tasawuf. Sementara itu, sebagai lembaga sosial artinya pesantren merupakan lembaga yang berakar kuat di masyarakat dan berpengaruh besar sebagai motor penggerak perubahan sosial yang terjadi di masyarakat.

Dalam bingkai perannya yang sangat luas dan kompleks tersebut, dapat ditarik suatu

pesantren menggunakan pendekatan yang melihat pendidikan sebagai bagian integral dari totalitas kehidupan manusia. Karenanya, upaya untuk memahami sistem pembinaan di pesantren mesti dimaknai dengan pendekatan holistik sesuai dengan prinsip pendidikan islam itu sendiri yang menawarkan konsep pendidikan seumur hidup (minal mahdi ilallahdi).

\section{PENGEMBANGAN PADA PONDOK PESANTREN}

Pengembangan (developing) merupakan suatu upaya untuk meningkatkan kompetensi teknis, konseptual, teknis dan moral para pegawai dengan kebutuhan pekerjaan atau jabatan melalui pelatihan dan pendidikan.sehingga perlu adanya pengembangan pondok pesantren baik itu dari sumber daya manusia (SDM), manajemen pondok, perekonomian pondok dan lain sebagainya, yang bertujuan untuk meingkatkan berbagai keterampilan yang ada di pondok pesantren dan meningkatkan pengembangan pondok pesantren di lingkungan masyarakat.

Kini dunia industri dan perkembangan teknologi sudah menjadi andalan dunia modern, maka sebenarnya faktor peranan sumber daya manusia mejadi sangat penting dan tidak bisa lagi diabaikan. Karena itu sebagai hasilnya justru sumber daya manusialah yang akan menentukan apakah tujuan perkembangan teknologi dapat tercapai dengan tepat. Sehingga para kiai dan banyak pihak mempunyai peran dan tanggung jawab agar out puts dari pesantren mempunyai 
bekal yang cukup dalam perkembangan teknologi di masa sekarang ini. Tentunya pengembangan yang dibutuhkan bukan hanya pengembangan SDM di masyarakat saja tapi juga pengembangan SDM di pondok pesantren. Pengembangan SDM pondok pesantren merupakan hal penting selain untuk mengembangkan kreativitas santri tapi juga untuk meningkatkan kualitas pesantren. Secara rinci disebutkan bahwa ada tujuh manfaat dari penyelanggaraan program pengembangan (Siagian. 1999:183).

Pertama, peningkatan produktivitas kerja organisasi sebagai keseluruhan antara lain tidak terjadinya pemborosan, terjalinnya kerja sama diantara satuan kerja, lancarnya koordinasi, sehingga organisasi bergarak sebagai satu kesatuan yang utuh. Kedua, terjalinnya hubungan yang harmonis antara atasan dengan bawahan, karena terjadi pendelegasian tugas, interaksi yang didasarkan pada sikap dewasa secara teknikal maupun intelektual, saling menghargai dan adanya kesempatan untuk berfikir dan bertindak melakukan inovasi. Ketiga, proses pengambilan keputusan yang lebih cepat dan tepat dengan melibatkan seluruh komponen yang bertanggung jawab dalam penyelenggaraan program. Keempat, meningkatkan etos kerja dalam organisasi dan komitmen untuk kemajuan menjadi lebih baik. Kelima, mendorong sikap keterbukaan manajemen dengan gaya manajerial partisipatif. Keenam, terjalinnya komunikasi yang efektif yang mengakibatkan lancarnya proses perumusan kebijakan operasional dan organisasi. Ketujuh, penyelesaian konflik secara fungsional yang melahirkan tumbuh subur rasa persatuan dan suasana kekeluargaan di lingkungan organisasi.

Pengembangan yang di lakukan oleh kementerian Agama kota palangka Raya pada lembaga pondok pesantren dari tradisional ke arah mandiri dan berdaya saing dalam menciptakan efektifitas karya.

\section{HASIL DAN PEMBAHASAN}

Dari hasil wawancara (202I) dengan pengelola pondok pesantren Kasi Pendidikan Diniyah dan Pondok Pesantren Kota Palangka Raya.Pembinaan Pada Pondok Pesantren pertama dari segi administrasi mengenai efektifitas penggunaan Emis (Education Management Information System),yang merupakan sistem informasi yang dikembangkan oleh Kementerian Agama untuk memudahkan input data sekolah, pondok pesantren dan pendidikan tinggi Islam,untuk semua kelengkapan administrasi pelaporan permohonan dan pertanggung jawaban bantuan dari pemerintah terkait dan pihak-pihak terkait/mitra kementerian agama pada pondok pesantren.Sehingga dapat terpantau kelengkapan data keaktifan pendidik dan peserta didik.kedua dalam hal Kesehatan di laksanakan dengan kolaborasi dengan Dinas Kesehatan terkait penyebaran wabah covid 19 dengan cara di adakan sosialasi dalam penerapan protokol kesehatan.Bahkan sebelum adanya wabah covid 19 juga sudah diadakan sosialisasi mengenai pentingnya kesehatan bekerja sama dengan Tim puskesmas yang diadakan sekali dalam setahun. Ketiga Edukasi yaitu pembinaan tentang kurikulum yang di gunakan yang 
Rip'ah, 202I,Data,Kriteria,Pembinaan Dan Pengembangan Pondok Pesantren Sekota Palangka Raya menyesuaikan dengan tingkatan yang ada pada lapangan biasanya masalah permintaan data pondok pesanatren Salafiyah dan pendidikan kesetaraan.Pendidikan salafiyah masih bersifat tradisional mempelajari tentang kitab kuning/mengaji sedangkan pendidikan kesetaraan bersifat formal/kombinasi di mana pondok pesantren tersebut memiliki tingkatan sekolah sebagai mana sekolah umum.

Pengembangan yang di lakukan oleh kementerian Agama Kota Palangka Raya Pada lembaga pondok pesantren (Wawancara dengan Kasi Pend.Diniyah dan Pondok Pesantren:202I) menghimbau/menjadikan pondok pesantren dari yang sifatnya tradisional ke arah mandiri dan berdaya saing dalam menciptakan efektifitas karya tidak hanya menonjol dari skill pengetahuan tentang keagamaan saja,namun juga memberikan life skill kepada santri,seperti adanya Budidaya ikan,perkebunan,dan dekorasi sablon.

Pengembangan pondok pesantren dari segi kelembagaan Kemenag Kota Palangka Raya mencoba untuk mencarikan mitra untuk memberikan bantuan sesuai dengan kebutuhan yang di perlukan ataupun membantu pengembangan sarana dan prasarana yang di butuhkan untuk membantu mengembangkan pondok pesantren.Adapun upaya dalam meningkatkan manajemen lembaga dengan memperkuat SDM yang menangani administrasi untuk menangani data-data seperti membuat data pondok pesantren,pelaporan terkait data yang di kirimkan ke Diknas sebagai syarat untuk bisa ikut ujian kesetaraan bagi santri tingkat akhir sesuai dengan tingkatan sekolah.Kendala di terkadang lambat direspon terkait keterbatasan SDM pada pondok pesantren dan juga masalah jaringan karena semua data harus di akses melalui web yang sudah di tentukan.

\section{E. KESIMPULAN}

Sistem pembinaan di pesantren hakikatnya adalah totalitas dari seluruh rangkaian kegiatan pembinaan di pondok dengan unsurunsurnya yang saling mempengaruhi dan terpadu dalam suatu sistem yang diarahkan pada pencapaian tujuan pendidikan yaitu membentuk keperibadian santri yang islami. Unsur-unsur dari sistem pembinaan di pesantren adalah elemenelemen pesantren itu sendiri yang meliputi Kiai, santri, masjid, asrama dan kitab-kitab klasik (kitab kuning).

Sistem pembinaan di pesantren dibangun dengan pendekatan holistik yang melihat pendidikan sebagai bagian integral dari totalitas kehidupan seorang muslim. Karena itu, pendidikan di pesantren didesain untuk menyentuh seluruh aspek kehidupan santri.

Pembinaan dan Pengembangan yang di lakukan oleh Kementerian Agama Kota Palangka Raya melalui Kasi Pendidikan Diniyah dan Pondok Pesantren pada lembaga pondok pesantren dari yang bersifat tradisional mewujudkan ke arah mandiri dan berdaya saing dalam menciptakan efektifitas karya.Tidak hanya menonjolkan dari skill keagamaan saja namun juga menghimbau dan memberikan life skill kepada para santri.Sehingga di harapkan santri 
yang telah lulus dari Pondok Pesantren dapat bersaing di masyarakat.

\section{DAFTAR PUSTAKA}

Wawancara dengan Kasi Diniyah dan Pondok Pesantren Kota Palangka Raya,(202I)

Wawacara dengan Operator EMIS Kanwil Kemenag Provinsi Kalteng,(2021)

Petunjuk Teknis Izin Operasional Pondok Pesantren Keputusan Direktur Jenderal Pendidikan Islam Nomor 3668 Tahun 2019

Tadbir: Jurnal Manajemen Dakwah Volume 3, Nomor 2, 2018, 83-102 Strategi Pengembangan Pondok Pesantren AlMu'awanah dalam Meningkatkan Kreativitas Santri Fakultas Dakwah dan Komunikasi, UIN Sunan Gunung Djati Bandung 2018

Abdul Kadir,Sistem Pembinaan Pondok Pesantrn,Dosen Jurusan Tarbiyah STAIN Sultan Qaimuddin Kendari

Pembantu Ketua I STAIN Sultan Qaimuddin Kendari 202I

Nurtia Rahmat, Pesantren Modern di Medan, (Disertasi Universitas Sumatera Utara: Unpublished)

Manfred Ziemek, Pesantren Dalam Perubahan Sosial, Jakarta: P3M, 1986

Umiarso \& Nur Zazin, Pesantren Di Tengah Arus Mutu Pendidikan; Menjawab Problematika Kontemporer Manajemen Mutu Pesantren Semarang: Rasail Media Group, 20II)
Muhammad Idris Jauhari, Sistem Pendidikan Pesantren,Sumenep: Al-Amin Printing, 2002

Sunarti, dkk. Pola Pengasuhan Anak Secara Tradisional di Kelurahan Kebagusan Daerah Khusus Ibu Kota Jakarta,Jakarta: Depdiknas, 2009

Tim Penyusun Kamus Pusat Pembinaan dan Pengembangan Bahasa, Kamus

Besar Bahasa Indonesia,Jakarta: Balai Pustaka, 1996.

Nurcholish Madjid, Bilik-Bilik Pesantren, Jakarta:Paramadina.

Poerwadarminta, Kamus Besar Bahasa Indonesia, 1984.

Departemen Agama RI Direktorat Jendral Kelembagaan Agama Islam Direktorat Pendidikan Keagamaan dan Pondok Pesantren,Grand Design Pendidikan Keagamaan dan Pondok Pesantren 20042009,Jakarta,2005

Ramdhani, M. T., Lastaria, L., \& Ariyadi, A. (2019). Pembelajaran Ekonomi dalam Islam pada Materi Mudharabah di Pondok Pesantren. Anterior Jurnal, 19(I), $32-40$.

Ramdhani, M. T., LASTARIA, L., \& ARIYADI, A. (2020, September). PEMBELAJARAN EKONOMI DALAM ISLAM PADA MATERI SYIRKAH DI PONDOK PESANTREN. In Proceeding Antasari International Conference (Vol. I, No. I).

Syaikhu, S., Ariyadi, A., \& Norwili, N. (2020). Fikih Muamalah: Memahami Konsep dan Dialektika Kontemporer. 
